\title{
THE RELATIONSHIP BETWEEN BOARD OF DIRECTORS AND SUSTAINABILITY REPORTING: AN EMPIRICAL STUDY IN GERMAN LARGE LISTED FIRMS
}

\author{
Thi Thuc Doan Nguyen ${ }^{1}$ \\ ${ }^{1}$ Faculty of Management and Economics, Tomas Bata University in Zlín, nám. T. G. Masaryka 5555, 76001 Zlín, \\ Czech Republic
}

Link to this article: https://doi.org/10.11118/actaun202068010211

Received: 7. 3. 2019, Accepted: 20.11. 2019

To cite this article: NGUYEN THI THUC DOAN. 2020. The Relationship Between Board of Directors and Sustainability Reporting: An Empirical Study in German Large Listed Firms. Acta Universitatis Agriculturae et Silviculturae Mendelianae Brunensis, 68(1): 211-218.

\begin{abstract}
To improve quality of sustainability reporting, Global Reporting Initiative (GRI) guidelines have been issued and widely applied. Board of directors' characteristics can be seen as essential factors to facilitate the implementation of these practices. This paper aims to investigate the relationship between board of directors and GRI adherence in sustainability disclosures. The research uses Tobit regression for 388 observations from 97 German listed firms in the period from 2013 to 2016. The findings indicate significant negative relation between board size and GRI adherent level of sustainability reporting. Further analysis is implemented for environmentally friendly and sensitive industries. The results maintain the same for board size, and reveal positive impact of board committees on GRI adherence of sustainability reporting in sensitive industry.
\end{abstract}

Keywords: GRI adherent level, board of directors, sustainability reporting

\section{INTRODUCTION}

Sustainability has been considered as an important reporting topic for firms over the past decade. If a sustainability report achieves the transparency and accountability, it can help firms measuring and communicating the impact of their economic, environmental, social, and governance performance. At the same time, this report can also be a tool to promote the firms' awareness toward their business risks and opportunities, then to be able to adjust into more proper operation and management strategies (Aktas, Kayalidere, and Kargin, 2013). Therefore, the important issue that firms need to do is not simply making a sustainable report, but to ensure that the report is clear, transparent and accountable.
One of the now widely used standards of sustainable reporting guidelines is the Global Reporting Initiative (GRI). About 63\% of the largest 100 firms and 75\% of firms in the Global Fortune 250 have applied GRI framework for their sustainability reports (KPMG, 2017). Thus, it is understandable that the GRI adherent level, which indicates how well a firm complies with GRI guidance, is usually applied to measure the transparency status of firms' sustainability reports.

The concept of corporate sustainability is not standing alone but often has an inter-linkage with corporate governance. In more details, whether or not being able to achieve a high quality sustainability report following GRI standard may greatly depends on the role of the board of directors. Kolk (2008) 
confirms that managers and directors' motivation, values and choices can impact sustainability disclosures. Majeed, Aziz, and Saleem (2015) also emphasize the importance of corporate governance in achievement of a successful sustainability target.

In regard to sustainable reporting development in Europe, Germany is considered as a pioneer country (Welford, 2004). Sustainability reporting has become compulsory in German since the beginning of 2017; however, companies still have flexibility in choosing suitable standards to prepare sustainability reports and on how to disclose non-financial information. These flexibilities may lead to significant differences among companies' sustainability reports.

Due to these issues, this paper concentrates on investigating the relationships between board of directors and GRI adherent of sustainable reporting in German listed firms. Research question is raised on whether listed German firms, which are regulated under the German Corporate Governance Code to have proper board compositions and activities, can ensure the transparency of sustainability reports within GRI framework.

Along with development of main model to investigate the research question, impact of industry on the main model is also tested in a complementary research. Industry factor is taken into account as corporate social activities can be varied in firms which belong to different industries (Jerkins, 2006). These differences may affect on how firms report their sustainability activities. Therefore, industry type is considered as one of the impact factor in research relating to sustainability (Svensson et al., 2009).

\section{Literature Review and Hypotheses Development}

German Corporate Governance Code is established and introduced under the form of primary regulations and standards for management and supervision of German listed firms. The Corporate Governance Code provides recommendations, makes suggestions, and regulates the corporate governance procedures, in which the board of directors is an important element. Regarding to board of directors, main recommendation is referred to determining and publishing objectives for board compositions (Article 5.4.1). These objectives include identification of sufficient number of independent members on board, and target number of females on board (Article 5.4.1). Based on firms' conditions and number of members, board of directors is required to form appropriate committees (Article 5.3.1). As The Code also focuses on ethical and social perspectives, the above recommendations will be taken into account when testing the relationship between board of directors and sustainability disclosure.

\section{Board Size and Sustainability Disclosures}

Board size is one of the most significant elements in the board of directors' structure (Dalton et al., 1999). Frias-Aceituno, Rodriguez-Ariza, and GarciaSanchez (2012) state that large board may facilitate the implementation of sustainability practices, sustainability disclosures, and corporate investment. As for German Corporate Governance Code (2015), it is recommended that the board should be structured with members that have knowledge, ability and experience to complete the tasks (Article 5.4.1). In order to achieve the recommendation, it is more likely that if board has more members, the possibility to have more expert experience, more advanced ability and knowledge to solve problems will be higher. With these advantages, it is assumed to facilitate firms' performance in sustainability disclosures.

Hypothesis 1: The GRI adherent level of sustainability reports is higher in firms that have higher number of board members.

\section{Board Independence and Sustainability Disclosures}

The independent status of a board member is satisfied if that member does not have personal or business connection with the firm, its management, its major shareholders, or an enterprise that may cause conflicts of interests (German Corporate Governance Code, 2015). The independence of board members plays a significant contribution in firm's activities, especially on firm information transparency (Abdullah, 2004). Webb (2004) discovers board with more independent members tends to be more responsible on social issues.

According to German Corporate Governance Code (2015), board of directors is recommended to include adequate number of independent members on board and to avoid including more than two former management bodies (Article 5.4.2). According to this recommendation, it is asserted that independent member plays an important role in board composition. Therefore, it is supposed that higher number of independent member on board has better impact on GRI adaptation.

Hypothesis 2: The GRI adherent level of sustainability reports is higher in firms that have more independent board members.

\section{Board Diversity and Sustainability Disclosures}

Female directors, with different approaches and communication can create different impact during the corporate management (Huse and Solberg, 2006). Female members are also considered more hardworking and concentrating on inspection than male members (Adams and Ferreira, 2009). Smith, Smith, and Verner (2006) confirm the important position of female directors as they can comprehend the market better than male members, improve corporate reputation in the awareness of community, and enhance firm perception on business environment. 
German Corporate Governance Code requires board of directors to include minimum of 30 percent female or male members (Article 5.4.1). In line with the rule, the paper confirms the critical roles of female directors in board and assumes that they will have positive impact on facilitating firm to comply with sustainability practices.

Hypothesis 3: The GRI adherent level of sustainability is higher in firms that have higher female members in board.

\section{Board Subcommittees and Sustainability Disclosures}

To be able to counsel effectively in specific issues, board committees are formed with appropriate members who have capacity in that matter. German Corporate Governance Code (2015) advises board of directors to form subcommittees with adequate capacity to counsel the board (Article 5.3.1). Types and number of the committees shall be considered according to company's condition and number of members. As members in one committee can become members in other committees, their understanding in wide ranges of firm's activities can support them in effectively solving firm issues. Therefore, the more committees are available, the higher possibilities for members to comprehend company operations and provide more appropriate advices. In relating to sustainability disclosure, the following hypothesis is developed.

Hypothesis 4: The GRI adherent level of sustainability reports is higher in firms that have more subcommittees in board of directors.

\section{Board Meetings and Sustainability Disclosures}

Board activities can be illustrated by term of board meetings. More frequent meetings can reduce information asymmetry in earnings (Kanagaretnam, Lobo, and Whalen, 2007), provide occasions for board members to share information, to distribute more effective workload, and to assign appropriate committees tasks (Laksmana, 2008). German Corporate Governance Code (2015) requires board with codetermination to held the meetings separately, probably with or without management board member in necessary circumstances (Article 3.6). In addition, if there is meeting participated rate of only half or less, this should be noted in the board of directors report (Article 5.4.7). With these regulations, it is assumed that the higher number of meetings to be hold, the higher possibility that board of directors achieves its tasks and responsibilities.

Hypothesis 5: The GRI adherent level of sustainability reports is higher in firms that have more Board of directors' meetings.

\section{MATERIALS AND METHODS}

\section{Data Collection}

As GRI issued its updated guideline version GRI-G4 in 2013, the research data is collected during the period 2013-2016 in order to cover the most current GRI adherent levels including G3, G3.1 and G4 versions. Within this period, 97 listed German firms, which have information relating to GRI adherent levels, are found in GRI Report List Database each year. Hence, the paper collects totally 388 observations from GRI database during research period.

With the list of companies, annual reports in four years were downloaded from companies' websites to gather information about number of board members, number of independent members, number of female members, number of meetings, number of committees and financial data. The other variables such as, GRI adherent level, company's industrial type, and external assurance status are collected from GRI reports list database. Founded year is searched on the firms' history.

\section{Dependent Variable Measurement}

GRI adherence from 2013 to 2016 consists of six types which include (i) GRI-Standard which is published at the end of 2016, (ii) GRI-G4 which is introduced in 2013, (iii) GRI-G3.1 which is updated from G3 and issued in 2011, (iv) GRI-G3 which is launched in 2006, (v) Citing GRI which indicates reports refer to GRI Guideline without having a GRI Content Index, and (vi) Non-GRI which indicates reports that do not fall under the mentioned categories.

As being issued at the end of 2016, GRI-Standard has not been applied by any firm in the research period. For GRI-G4, there are two adherent levels: Comprehensive and Core. Comprehensive option is developed from the Core option by requesting further disclosure of organization's policy, governance, and moral values and reliability. Therefore, G4-Comprehensive can be seen to have greater transparency than G4-Core. As for GRI-G3 and GRI-G3.1, compliance rate is graduated ranking from $\mathrm{A}^{+}, \mathrm{A}, \mathrm{B}+, \mathrm{B}$, and $\mathrm{C}$ according to how well the firm can fulfill the recommendations. For all current GRI versions, if integrated report does not declare the adherent status, it is classified as 'Undeclared' which is also classified as lowest rank referring to transparency under each GRI type.

In according to previous research of Fuente et al. (2017) and Prado-Lorenzo et al. (2009) relating to setting index for adherent levels, this paper determines the scale according GRI types and adherent level as indicated above. This means the lowest value (0) applies for Non-GRI sustainability report and the highest value (16) applies GRI-G4 type. 
I: GRI adherent level index

\begin{tabular}{|c|c|c|c|c|c|}
\hline GRI Type & Adherent level & Index & GRI Type & Adherent level & Index \\
\hline Non-GRI & & 0 & \multirow{6}{*}{ G3.1 } & Undeclared & 8 \\
\hline Citing GRI & & 1 & & C & 9 \\
\hline \multirow{7}{*}{ G3 } & Undeclared & 2 & & B & 10 \\
\hline & C & 3 & & $\mathrm{~B}^{+}$ & 11 \\
\hline & B & 4 & & A & 12 \\
\hline & $\mathrm{B}^{+}$ & 5 & & $\mathrm{~A}^{+}$ & 13 \\
\hline & A & 6 & \multirow{3}{*}{ G4 } & Undeclared & 14 \\
\hline & $\mathrm{A}^{+}$ & 7 & & Core & 15 \\
\hline & & & & Comprehensive & 16 \\
\hline
\end{tabular}

Source: Author's compilation and classification

\section{Independent Variables Measurement}

Following the studies of Liao, Luo, and Tang (2015), Guest (2008), and Hasan and Butt (2009), measurements of the five variables: board size, board independence, board diversity, board committees, and board meeting are examined and summarized in Tab. II.

\section{Control Variables}

Firm size can reflect firm's adherent level to social commitment (Teoh and Thong, 1984), then firm size becomes the first control variable in the research. Cormier and Gordon (2001) conclude that sustainability transparency is highlighted in large firms due to responsibility objectives. Aside firm size, firm age is another factor that may impact sustainability disclosures. Perennial companies are more likely to have more experience on sustainability association and status (Roberts, 1992). Thirdly, firm performance is found to have positive impact on sustainability transparency. Tagesson et al. (2009) state that profitability form better firm performance will be the resource to expend for sustainability activities (Tagesson et al., 2009), and can make management less hesitate in providing more sustainability information (Haniffa and Cooke, 2005). Therefore, it is assumed that GRI adherent level of sustainability reports is higher in larger size firm, in older firm, and in higher profitable companies.

Sustainability report itself cannot provide the assurance for information transparency quality (Junior, Best and Cotter, 2014); therefore, assurance of these reports can be seen as a mechanism to enhance the reports' trustworthiness. The quality of these report are better when the assurance are supplied by external bodies such as auditing companies (Simnett, Vanstraelen and Chua, 2009). Hence, it is proposed that firms which recruit external assurance to audit their sustainability reports tend to have high compliance performance with sustainability practices.
Measurements of firm size, firm age and firm performance are followed previous research of Al-Najjar (2014), Chen (2007), Gurcharan (2010) and Coad, Segarra and Teruel (2013). Regarding to external assurance, dummy variables with 0 for sustainability report which is not audited, and 1 for sustainability report which is audited by an external body are applied.

\section{Research Method}

Tobit regression is applied to test the hypothesized relationship. The study aims to find out the relation between one dependent variable, which is scaled from 0 to 16 , and several independent variables. Therefore, Tobit regression can be considered as an appropriate method to examine the relationship as it tolerates reflection of both end of rating scale (Fuente et al., 2017). Moreover, Tobit regression consists of information from censored and uncensored observation by applying maximum likelihood, therefore, it provides efficient and consistent coefficient estimations (Fuente et al.,

II: List of independent and control variables measures

\begin{tabular}{|c|c|}
\hline Variables & Measurements \\
\hline Board size & Number of board members \\
\hline $\begin{array}{l}\text { Board } \\
\text { independence }\end{array}$ & $\begin{array}{l}\text { Proportion of independent members } \\
\text { on board }\end{array}$ \\
\hline Board diversity & $\begin{array}{l}\text { Proportion of female members } \\
\text { on board }\end{array}$ \\
\hline Board committees & Number of board committees \\
\hline Board meetings & Number of board meetings \\
\hline Firm size & Logarithm of total assets \\
\hline Firm age & $\begin{array}{l}\text { Difference between current year } \\
\text { and founded year }\end{array}$ \\
\hline
\end{tabular}

Firm performance Net Income/Total assets (ROA)

External assurance 1: Yes, 0: No

Source: Author's compilation and collection from previous research 
2017). With this model, individual heterogeneity can be controlled via the random effects estimator by observing the research data over different points of time. As the research data of this paper is a panel data which observes the same companies' information over several continuous years, hence heterogeneity can be seen to be effectively controlled.

The equation of Tobit regression model which based on panel data are formulated as follow:

$$
\begin{aligned}
\text { GRIlevel }_{i t}= & \beta_{0}+\beta_{1} \text { boardsize }_{i t}+\beta_{2} \text { independence }_{i t}+ \\
& +\beta_{3} \text { diversity }_{i t}+\beta_{4} \text { committees }_{i t}+ \\
& +\beta_{5} \text { meetings }_{i t}+\beta_{6} \text { firmsize }_{i t}+ \\
& +\beta_{7} \text { age }_{i t}+\beta_{8} \text { performance }_{i t}+ \\
& +\beta_{9} \text { externalassurance }_{i t}+\varepsilon_{i t},
\end{aligned}
$$

where GRIlevel is GRI Adherent level, $i_{1,388}$ captures firms, $\beta_{0}$ is the constant, $\beta_{1, \ldots, 9}$ are estimated coefficients of the explanatory variables, $\varepsilon$ is the error term, and $t_{2013, \ldots, 2016}$ captures the research period.

\section{Descriptive Statistics}

Significant variances incur in board size, board independence, board meetings and firm age. The average board size includes 13 members, which is approximate to the real firm size of 12 members. This size occupies more than $37 \%$ of all board size in the observations. Relating to independent board, while some firms have no independent member, the others have all members to be independent. Firms with no independent member confirmed their needs for the internal expertise to supervise firms' activities and decided to violate the code recommendation. For firms that achieve 100\% of independent members, it is stated in the corporate governance reports that all members are satisfy the independent criteria according to Article 5.4.2 of the Code. As for board meetings, while average board meetings are just 19 times, the highest observation reaches 84 meetings. This observation of 84 meetings only appears once, and the regular number of meetings is usually under 40 times. For firm age, while some companies are in really young ages, the others have a really long history. Indeed, 137 observations in the sample have firm age value of more than 100 years old. Moreover, average firm age of nearly 81 years old also confirm the long existence of the observed firms. For board diversity and board committees, many firms still have no female member and no committee. In addition, the average proportion of female on board is quite low at around $20 \%$ of all members.

\section{RESULTS AND DISCUSSION}

The regression results in Tab. III reveal the negative significant at 5\% coefficient in board size. The outcome of board size means that the greater of number of board member is the worse of firm's GRI adherent status is. The significant connection between board size and GRI adherent level is consistent, however, the impact between two variables is opposite from the hypothesis 1 . This result is consistent with previous research such as Prado-Lorenzo and Garcia-Sanchez (2010), and Kassinis and Vafeas (2002). Possible reasons for the adverse influence can be the bigger board size is the less coherent in decision making is, moreover, it seems to be incapable for large board size to determine firm strategies to prevent company from inappropriate sustainability practices (Kassinis and Vafeas, 2002). Jensen (1993) confirms this negative impact as large board involves dealing with more opinions which lead to decision making delay and inactively firm management.

As for board independence and board diversity, the regression results find no significant relationship with GRI adherent level. In the most current version of German Corporate Governance Code, the Code recommends firms to set clear targets for independent member and proportion of female on board. However, in reality, many firms violate from the recommendation as these targets seem to impair the flexibility in choosing board members. In addition, the requirement of at least 30\% of female on board is valid in 2016; hence, the impact of this requirement may be weak in the research period from 2013 to 2016 . With the results indicated from the research, it confirmed there are no impact between GRI adherent level with board independence and gender diversity.

The results also cannot indicate the influence of board committees and board meetings on GRI compliance status. The outcome relating to board meeting is similar to Kaeamanou and Vafeas (2005). With the findings, it cannot be asserted that GRI adherent level of sustainability reports is higher in firms that have more subcommittees and meetings.

III: Empirical results for all observations

\begin{tabular}{lccc}
\hline \multicolumn{1}{c}{ Variables } & Coefficient & $\mathrm{t}$ value & P value \\
\hline Board size & $-.335^{* *}$ & -2.41 & 0.017 \\
Board independence & .014 & 0.94 & 0.347 \\
Board diversity & .036 & 0.81 & 0.421 \\
Board committees & .570 & 1.42 & 0.158 \\
Board meetings & -.066 & -1.13 & 0.258 \\
Firm size & $1.876^{* *}$ & 2.41 & 0.017 \\
Firm age & $.131^{*}$ & 1.93 & 0.055 \\
Firm performance & -0.057 & -0.71 & 0.476 \\
External assurance & $7.056^{* * *}$ & 7.56 & 0.000 \\
\hline
\end{tabular}

* Significance at the $10 \%$ level

** Significance at the 5\% level

*** Significance at the $1 \%$ level 
IV: Empirical results for industry separation into sensitive and friendly sectors

\begin{tabular}{lcccc}
\hline \multicolumn{1}{c}{ Variables } & \multicolumn{1}{c}{ Environmentally sensitive industry } & \multicolumn{2}{c}{ Environmentally friendly industry } \\
\hline & Coefficient & P-value & Coefficient & P-value \\
\hline Board size & $-.339^{*}$ & .059 & $-.397^{*}$ & .056 \\
Board independence & .016 & .424 & .036 & .105 \\
Board diversity & .018 & .784 & .029 & .632 \\
Board committees & $2.397^{* * *}$ & .000 & -.830 & .148 \\
Board meetings & -.034 & .743 & -.017 & .811 \\
Firm size & $2.343^{* *}$ & .036 & $3.099^{* * *}$ & .007 \\
Firm age & $.030^{* *}$ & .002 & -.001 & .931 \\
Firm performance & -.024 & .762 & -.103 & .639 \\
External assurance & $6.385^{* * *}$ & .000 & $5.821^{* * *}$ & .000 \\
\hline Signifleance at the & & & & \\
\hline
\end{tabular}

* Significance at the $10 \%$ level

** Significance at the 5\% level

*** Significance at the $1 \%$ level

For control variables, firm size, firm age and external assurance have favorable significant influence on GRI adherent level. This means firm tends to adopt GRI guidelines more appropriately when it has bigger size, is founded earlier and implements external assurance for sustainability report. These outcomes are consistent with the assumption that made before except for the impact of firm performance. This suggests that firm profitability does not impact on GRI adherent level of observed firms.

\section{Complementary Results and Discussion}

Jenkins (2006) states that sustainability activities are different among firms depending on which industries the firms belong to. Environmental information tends to be provided more in environmental sensitive firms (Campbell, 2003; Hackston and Milne, 1996). This paper desires to test whether different behavior incur among independent and dependent variable if firm belongs to environmental sensitive and friendly sectors. Therefore, the data is divided into two groups, the first set includes 212 firms belong to environmental sensitive industry and the other set consist of 176 firms that are in environmentally friendly industry.

The regression results in Tab. IV are consistent with Tab. III in regarding to board size, firm size and external assurance for both data sets. However, when separating the data into two groups of industries, firm age has no longer impact on GRI adherent level of friendly industry. Unlike sensitive group, which have more activities that may negatively impact on environment and communities, friendly group, which have more stable activities involving the environment, may not need to gain more experience and capacity in implementing sustainability practice. For sensitive industrial firms, number of board committees has significant influences on GRI appliance level. This variance can be caused by the establishment of board committees lead to the improvement of board efficiency. And in environmentally sensitive firm, it is in need for board committees to focus on sustainability transparency. Therefore, the more committees are, it is likely that the more appropriate tasks are allocated among committees members to be able to provide proper advices which also include advices on implementing GRI guidance.

\section{CONCLUSION}

Sustainability reporting has received remarkable attention due to the sustainability development target of firms themselves as well as the requirements on mandatory sustainable disclosures and the increasing awareness of stakeholders about a transparent sustainability reporting. Among different sustainability reporting guidance, the GRI framework is most widely known and applied by firms worldwide in order to achieve a transparent and accountable sustainability report. Previous studies have shown some evidence that the transparency and accountability may be well affected by the corporate governance, especially the board of directors. Therefore, this study has further examined the relationship between board of directors and adherence status of firm when adopting GRI guidelines for sustainability reporting. The research is conducted on 97 listed firms in Germany which is considered as a leading nation in sustainability regulations. A total of 388 observations were collected from GRI Report List Database from 2013 to 2016 to cover current GRI guidance versions. 
This study finds significant relations between GRI adherent level with board size, firm size, firm age and external assurance on sustainability reports. The relation is adverse for board size and favorable for all the other threes. In addition, complementary analysis is implemented for two groups of industries: the sensitive and friendly with environment. The results for further regression maintain the same for board size, firm size and external assurance, however, firm age has no more influence on GRI adherent level of environmental friendly group. Moreover, positive impacts on dependent variable incur for board committees in sensitive industry and for firm age in friendly industry.

These findings contribute some insights to the academic and practical perspectives. More literature in sustainability reporting issues are generated through the study regarding to German large listed firm in the period between 2013 and 2016. For German large listed firms, factors in board of directors which can impact the application status of GRI can be observed. This in turn can provide approaches for firm to determine successful factors for implementing GRI.

In the meantime, different outcomes of the research also reveal a limitation in this paper as it has not examined the compliance of the whole Code, but only focus on board of directors composition and activities. Therefore, the result may not expose all the links between the guidance and code. Due to this limitation, further research on investigating the connection between the compliance with the whole German Corporate Governance Code and GRI adherent level can be performed.

\section{REFERENCES}

ABDULLAH, S. N. 2004. Board Composition, CEO Duality and Performance among Malaysian Listed Companies. Corporate Governance, 4(4): 47-61.

ADAMS, R. B. and FERREIRA, D. 2009. Women in the Boardroom and Their Impact on Governance and Performance. Journal of Finance and Economics, 94: 291-309.

AKTAS, R., KAYALIDERE, K. and KARGIN, M. 2013. Corporate Sustainability Reporting and Analysis of Sustainability Reports in Turkey. International Journal of Economics and Finance, 5(3): 113.

AL-NAJJAR, B. 2014. Corporate Governance, Tourism Growth and Firm Performance: Evidence from Publicly Listed Tourism Firms in Five Middle Eastern Countries. Tourism Management, 42: 342-351.

CAMPBELL, D. 2003. Intra- and Inter-Sectoral Effects in Environmental Disclosures: Evidence for Legitimacy Theory? Business Strategy and the Environment, 12(6): 357-371.

CHEN, M. H. 2007. Hotel Stock Performance and Monetary Conditions. International Journal of Hospitality Management, 26(3): 588-602.

COAD, A., SEGARRA, A. and TERUEL, M. 2013 Like Milk or Wine: Does Firm Performance Improve with Age?. Structural Change and Economic Dynamics, 24: 173-189.

CORMIER, D. and GORDON, I. M. 2001. An Examination of Social and Environmental Reporting Strategies. Accounting, Auditing and Accountability Journal, 14(5): 587-617.

DALTON, D. R., DAILY, C. M., JOHNSON, J. L. and ELLSTRAND, A. E. 1999. Number of Directors and Financial Performance: A Meta-Analysis. The Academy of Management Journal, 42(6): 674-686.

FRIAS-ACEITUNO, J., RODRIGUEZ-ARIZA, L. and GARCIA-SANCHEZ, I. M. 2012. The Role of the Board in the Dissemination of Integrated Corporate Social Reporting. Corporate Social Responsibility and Environment Management, 20(4): 219-233.

FUENTE, J. A., GACIA-SANCHEZ, I. M. and LOZANO, M. B. 2017. The Role of The Board of Directors in the Adoption of GRI Guidelines for The Disclosure of CSR Information. Journal of Cleaner Production, 141: 737-750.

GERMAN CORPORATE GOVERNANCE CODE. 2015. Deutscher Corporate Governance Kodex. [Online]. Available at: https://www.dcgk.de/en/code/archive.html [Accessed: 2017, June 17].

GUEST, P. M. 2008. The Determinants of Board Size and Composition: Evidence from the UK. Journal of Corporate Finance, 14(1): 51-72.

GURCHARAN, S. 2010. A Review of Optimal Capital Structure Determinant of Selected Asean Countries. International Research Journal of Finance and Economics, 47: 32-43.

HACKSTON, D. and MILNE, M. J. 1996. Some Determinants of Social and Environmental Disclosures in New Zealand Companies. Accounting, Auditing and Accountability Journal, 9(1): 77-108.

HANIFFA, R. M. and COOKE, T. E. 2005. The Impact of Culture and Governance on Corporate Social Reporting. Journal of Accounting and Public Policy, 24(5): 391-430.

HASAN, A. and BUTT, S.A. 2009. Impact of Ownership Structure and Corporate Governance on Capital Structure of Pakistani Listed Companies. International Journal of Business and Management, 4(2): 50-58. 
HUSE, M. and SOLBERG, A. G. 2006. Gender-related Boardroom Dynamics. How Scandinavian Women Make and Can Make Contributions on Corporate Boards. Women in Management Review, 21(2): 113-130.

JENKINS, H. 2006. Small Business Champions for Corporate Social Responsibility. Journal of Business Ethics, 67(3): 241-256.

JENSEN, M. C. 1993. The Modern Industrial Revolution, Exit, and The Failure of Internal Control Systems. The Journal of Finance, 48(3): 831-880.

JUNIOR, R. M., BEST, P. J. and COTTER, J. 2014. Sustainability Reporting and Assurance: a Historical Analysis on a World-Wide Phenomenon. Journal of Business Ethics, 120(1): 1-11.

KANAGARETNAM, K., LOBO, G. J. and WHALEN, D. J. 2007. Does Good Corporate Governance Reduce Information Asymmetry Around Quarterly Earnings Announcements? Journal of Accounting and Public Policy, 26(4): 497-522.

KARAMANOU, I. and VAFEAS, N. 2005. The association between corporate boards, audit committees, and management earnings forecasts: an empirical analysis. Journal of Accounting Research, 43(3): 453-486.

KASSINIS, G. and VAFEAS, N. 2002. Corporate Boards and Outside Stakeholders as Determinants of Environmental Litigation. Strategic Management Journal, 23(5): 399-415.

KOLK, A. 2008. Sustainability, Accountability and Corporate Governance: Exploring Multinationals’ Reporting Practices. Business strategy and the environment, 17(1): 1-15.

KPMG. 2017. Survey of Corporate Responsibility Reporting 2017. [Online] Available at: https:// assets.kpmg.com/content/dam/kpmg/xx/ pdf/2017/10/kpmg-survey-of-corporate-responsibilityreporting-2017.pdf [Accessed: 2018, May 12].

LAKSMANA, I. 2008. Corporate Board Governance and Voluntary Disclosure of Executive Compensation Practices. Contemporary Accounting Research, 25(4): 1147-1182.

LIAO, L., LUO, L. and TANG, Q. 2015. Gender Diversity, Board Independence, Environmental Committee and Greenhouse Gas Disclosure. The British Accounting Review, 47(4): 409-424.

MAJEED, S., AZIZ, T. and SALEEM, S. 2015. The Effect of Corporate Governance Elements on Corporate Social Responsibility (CSR) Disclosure: An Empirical Evidence from Listed Companies at KSE Pakistan. International Journal of Financial Studies, 3(4): 530-556.

PRADO-LORENZO, J. M. and GARCIA-SANCHEZ, I. M. 2010. The Role of the Board of Directors in Disseminating Relevant Information on Greenhouse Gases. Journal of Business Ethics, 97(3): 391424.

ROBERTS, R. W. 1992. Determinants of Corporate Social Responsibility Disclosure: An Application of Stakeholder Theory. Accounting, Organizations and Society, 17(6): 595-612.

SIMNETT, R., VANSTRAELEN, A. and CHUA, W. F. 2009. Assurance on Sustainability Reports: An International Comparison. The Accounting Review, 84(3): 937-967.

SMITH, N., SMITH, V. and VERNER, M. 2006. Do Women in Top Management Affect Firm Performance? A Panel Study of 2500 Danish Firms. International Journal of Productivity and Performance Management, 55(7): 569-593.

SVENSSON, G., WOOD, G., SINGH, J. and CALLAGHAN, M. 2009. Implementation, Communication and Benefits of Corporate Codes of Ethics: an International and Longitudinal Approach for Australia, Canada and Sweden. Business Ethics: A European Review, 18(4): 389-407.

TAGESSON, T., BLANK, V., BROBERG, P. and COLLIN, S. O. 2009. What Explains the Extent and Content of Social and Environmental Disclosures on Corporate Websites: A Study of Social and Environmental Reporting in Swedish Listed Corporations. Corporate Social Responsibility and Environmental Management, 16(6): 352-364.

TEOH, H. Y. and THONG, G. 1984. Another Look at Corporate Social Responsibility and Reporting: An Empirical Study in a Developing Country. Accounting, Organizations and Society, 9(2): 189-206.

WEBB, E. 2004. An Examination of Socially Responsible Firms' Board Structure. Journal of Management and Governance, 8(3): 255-277.

WELFORD, R. 2004. Corporate Social Responsibility in Europe, North America and Asia: 2004 Survey Results. Journal of Corporate Citizenship, 17: 33-52. 